\title{
Формирование механизма
}

\section{устойчивого развития угольной промышленности на основе нового подхода к использованию ресурсов при экосистемном взаимодействии}

\author{
АСТАФЬЕВА O.E. \\ Канд. экон. наук, \\ заведующий кафедрой экономики \\ и управления в строительстве \\ Государственного университета управления, \\ 109542, г. Москва, Россия, \\ e-mail:aoe@list.ru
}

Для угольной промышленности, как и для промышленных предприятий других отраслей, свойственны изменения в функционировании, продиктованные цифровыми трансформациями в рамках реализации программы «Индустрия 4.0», когда «умное» месторождение или «умное» предприятие являются необходимостью устойчивого развития отрасли и экономики страны в целом. Промышленные предприятия разрабатывают программы «Цифрового производства», в которых на начальных этапах предлагаются формировать новые бизнес-модели управления на базе цифровых решений. Исследования в области устойчивого развития промышленности и дальнейших форм функционирования и взаимодействия субъектов хозяйственной деятельности в цифровой среде позволили сформировать механизм устойчивого развития, настраиваемый под конкретную отрасль. В представленной статье изложен новый подход к формированию механизма устойчивого развития угольной промышленности на базе ресурсной модели и экосистемного взаимодействия. Модель устойчивого развития для угольной промышленности интерпретирована с учетом ресурсной составляющей и взаимодействий добывающих и логистических систем, что позволяет выстраивать новые схемы распределения ресурсов и оптимизации производственно-логистических операций.

Ключевые слова: механизм, устойчивое развитие, ресурсная модель, экосистемный подход, моделирование, оперативное управление, шахта, матрица устойчивости, балансовые потоки.

Для цитирования: Астафьева О.Е. Формирование механизма устойчивого развития угольной промышленности на основе нового подхода к использованию ресурсов при экосистемном взаимодействии // Уголь. 2021. № 6. С. 15-17. DOI: 10.18796/0041-5790-2021-6-15-17.

\section{ВВЕДЕНИЕ}

При формировании механизма устойчивого развития угольной промышленности [1] в условиях цифровых трансформаций меняются подходы к взаимодействию участников процессов добычи и переработки ресурса. Процессы взаимодействия участников цепочки создания добавленной стоимости носят более интеграционный характер в силу специфики взаимосвязи в экосистемном пространстве, формируемом в рамках цифровой среды как наиболее эффективной формы функционирования промышленности.

Концепция, заложенная в программе «Индустрия 4.0» [2, 3], ориентирует предприятия угольной промышленности на создание «цифровых месторождений» (ЦМ) как самонастраиваемых цифровых систем, выбирающих оптимальные режимы отработки и обеспечивающих контроль каждого процесса в реальном времени, осуществляемый операторами ЦМ. В этой связи, формируемые модели математического моделирования разработки угольных месторождений позволяют оценивать запасы и «спроектировать» конфигурацию пласта полезного ископаемого или вмещающего рудного тела, что особенно важно при определении объемов полезных ископаемых, извлекаемых из недр месторождения за единицу времени при применении новых подходов к использованию ресурсов при цифровой трансформации промышленности и интегрированной модели планирования добычи угля и сбыта [4] с целью обеспечения сбалансированности распределения ресурса по производственно-логистической цепи [5].

\section{ОБОСНОВАНИЕ НОВОГО ПОДХОДА К ИСПОЛЬЗОВАНИЮ РЕСУРСОВ ПРИ ЭКОСИСТЕМНОМ ВЗАИМОДЕЙСТВИИ}

Новый подход к использованию ресурсов при экосистемном взаимодействии обусловлен оптимизацией схем вскрытия угольных месторождений и полной автоматизацией отработки эксплуатационных блоков с целью поддержания оптимального режима разработки месторождения и формирования логистических операций как внутри, так и во вне, что позволяет сократить расходы на добычу и рас- 
пределение полезного ископаемого. Стратегии цифровизации промышленности ориентированы на реализацию таких программ, как: цифровое месторождение; цифровая логистика; цифровое управление запасами; цифровая финансовая отчетность; электронный документооборот [3].

Работа цифрового месторождения строится на основе цифровых моделей, основной задачей которых являются автоматизация и моделирование процессов планирования, оперативного управления горными работами, логистических процессов, что требует наличия соответствующей инфраструктуры, которую целесообразно формировать на основе экосистемного подхода как цифровую экосистему взаимодействия на платформенной основе, дающую возможность применения новых подходов к использованию ресурсов. Также следует отметить, что традиционная модель «ресурсы - процесс - результат» в условиях цифровой трансформации промышленности не может работать эффективно в силу того, что взаимодействия в новых условиях становятся взаимообусловленными, то есть ориентированными на формирование ценности в рамках экосистемы функционирующего угольного предприятия.

Роль механизма устойчивого развития угольной промышленности при экосистемном подходе берет на себя цифровая платформа [6], формирующая эффекты, способствующие обеспечению эффективного использования ресурсов в цепочке создания стоимости. Например, в работах таких ученых, как Дж. Нейсбит, Э. Тоффлер и Ф. Фукуяма [7, 8, 9], рассматриваются такие эффекты экосистемного (сетевого) взаимодействия, как эффект масштаба, влияющий на повышение конкурентоспособности предприятия, и рациональность использования ресурсов по схеме взаимодействий.

Модель устойчивого развития угольной промышленности целесообразно сформировать на основе ресурсной модели, в которой отразить основные ресурсные цепочки, включающие добывающее производство и логистическую систему. Тогда оптимальный уровень устойчивости можно определить в результате формирования матрицы устойчивости, в которой посредством анализа Big Data по ресурсной цепочке и определения свойств оптимизации потоков можно выстроить новые схемы распределения ресурсов и оптимизации производственно-логистических операций (см. рисунок).

Таким образом, можно сформировать уравнение определения устойчивости элементов в каждой ресурсной цепочке:

$$
\left.M_{y}\left(Y_{o p}\right)=[R: p: s) ;(n: a) ;(E: a)\right],
$$

где $R$ - ресурсы; $p$ - объем потребления; $s$ - замещение; $n$ - регулятор; $E$ - эффект; $a$ - аллокация.

При установлении зависимостей в ресурсной цепочке производственной и логистической систем можно вносить изменения в нормативы добычи ресурса с учетом прогнозного потребления в условиях цифровой трансформации экономики, изменения технологий и регулирования балансовых потоков. Экосистемный подход в организации взаимодействия по ресурсным цепочкам позволяет по-новому создавать ценность ресурса.

\section{ЗАКЛЮЧЕНИЕ}

Практика применения цифровых технологий в угольной промышленности на данный момент мало изучена [10, 11, 12]. Однако современные цифровые системы, которые уже нашли применение в промышленности, показывают сокращение допускаемых ошибок при подаче ресурса, формировании оптимального плана загрузки оборудования на шахтах и сокращение отходов добычи и обогащения. Математические модели, использующие принципы концепции «цифровых двойников», позволяют определить по ресурсным цепочкам рациональные технологические схемы шахты с учетом параметров всех технологических процессов ее подсистем и выстроить комплексную модель «Цифрового месторождения» на основе экосистемного подхода, что обеспечивает рациональную организацию добычи и использования ресурса.

\section{Список литературы}

1. Новоселов С.В., Мельник В.В., Агафонов В.В. Экспортно ориентированная стратегия развития угольных компаний России - основной фактор обеспечения их финан-
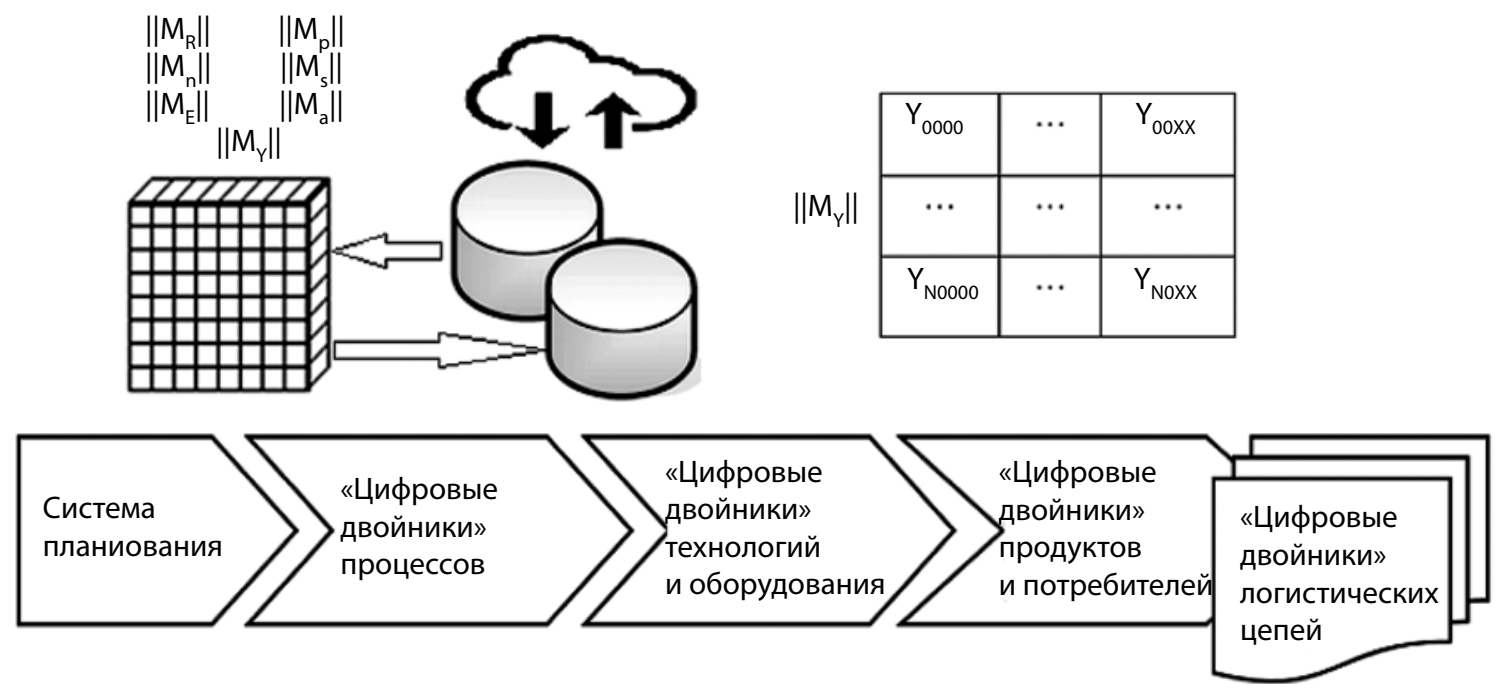

Составные блоки механизма устойчивого развития промышленности на основе нового подхода к формированию ресурсной модели в рамках экосистемного взаимодействия (на примере угольной промышленности; фрагмент) 
совой устойчивости // Уголь. 2017. № 11. С. 54-56. DOI: 10.18796/0041-5790-2017-11-54-56.

2. Плакиткин Ю.А., Плакиткина Л.С. Анализ базовых направлений реализации «Программ Индустрия - 4.0» и «Цифровая экономика Российской Федерации» // Горная промышленность. 2018. № 1. С. 22-28.

3. Хиллер Б. «Индустрия-4.0» - умное производство будущего. Опыт «цифровизации» Германии / Материалы VI Международного форума «Информационное моделирование для инфраструктурных проектов и развития бизнесов Большой Евразии». М., 2017.

4. Астафьева О.Е. Особенности формирования механизма устойчивого развития промышленности на основе эффективного использования ресурсов // Вестник университета. 2020. № 7. С. 45-50.

5. Астафьева О.Е. Формирование механизма устойчивого развития угольной промышленности //Уголь. 2021. № 3. C. 10-13. DOI: 10.18796/0041-5790-2021-3-10-13.
6. Тимофеева Т.Б., Оздоева Э.А. Анализ мирового опыта в создании цифровых платформ и связанных с ними рисков // Управление. 2020. Т. 8. № 3. С. 112-122.

7. Тоффлер Э. Шок будущего. М.: ООО «Издательство ACT», 2002. 557 c.

8. Нейсбит Дж. Мегатренды. М.:ООО «Издательство АСТ», ЗАО НПП «Ермак», 2003. 380 с.

9. Фукуяма Ф. Великий разрыв. М: ООО «Издательство АСТ», ЗАО НПП «Ермак», 2004. 474.

10. Губанов Д.А. Производство и поставки угля в России / Информационно-аналитический обзор (март 2020). М.: ЦДУ ТЭК, 2020. 28 с.

11. Таразанов И.Г., Губанов Д.А.Итоги работы угольной промышленности России за январь - декабрь 2019 года //Уголь. 2020. № 3. C. 54-69. DOI: 10.18796/0041-5790-2020-3-54-69.

12. Таразанов И.Г., Губанов Д.А.Итоги работы угольной промышленности России за январь - март 2020 года // Уголь. 2020. № 6. C. 23-34. DOI: 10.18796/0041-5790-2020-6-23-34.

Original Paper

ECONOMIC OF MINING

UDC 658.155:622.33 @ O.E. Astafyeva, 2021

ISSN 0041-5790 (Print) • ISSN 2412-8333 (Online) • Ugol' - Russian Coal Journal, 2021, № 6, pp. 15-17

DOI: http://dx.doi.org/10.18796/0041-5790-2021-6-15-17

Title

FORMATION OF A MECHANISM FOR THE SUSTAINABLE DEVELOPMENT OF THE COAL INDUSTRY BASED ON A NEW APPROACH TO THE USE OF RESOURCES IN ECOSYSTEM INTERACTION

\section{Author}

Astafyeva O.E. ${ }^{1}$

1 State University of Management, Moscow, 109542, Russian Federation

\section{Author's Information}

Astafyeva O.E., PhD (Economic), Associate Professor, Head of Economics and management in construction department, e-mail: aoe@list.ru

\section{Abstract}

The coal industry, as well as industrial enterprises of other industries, is characterized by changes in functioning dictated by digital transformations within the framework of the "Industry 4.0" program, when a "smart" field or a "smart" enterprise is a necessity for the sustainable development of the industry and the country's economy as a whole. Industrial enterprises develop “Digital Production" programs, in which at the initial stages it is proposed to form new business models of management based on digital solutions. Research in the field of sustainable industrial development and further forms of functioning and interaction of economic entities in the digital environment, allowed us to form a mechanism for sustainable development, customized for a specific industry. The article presents a new approach to the formation of a mechanism for the sustainable development of the coal industry based on the resource model and ecosystem interaction. The model of sustainable development for the coal industry is interpreted taking into account the resource component and the interaction of mining and logistics systems, which allows us to build new schemes for resource allocation and optimization of production and logistics operations.

\section{Keywords}

Mechanism, Sustainable development, Resource model, Coal industry, Min ing, Processing, Ecosystem approach, Modeling, Operational management, Mine, Sustainability matrix, Balance flows.

\section{References}

1. Novoselov S.V., Melnik V.V.\& Agafonov V.V. Export-oriented development strategy of the coal companies of Russia - the main factor ensuring their financial stability. Ugol', 2017 (11), pp. 54-56. (In Russ.). DOI: 10.18796/00415790-2017-11-54-56.

2. Plakitkin Yu.A. \& Plakitkina L.S. Analysis of the basic directions of the implementation of the Industry-4.0 and Digital Economy of the Russian Federation Programs. Gornaya promyshlennost, 2018, (1), pp. 22-28. (In Russ.).

3. Hiller B. "Industry 4.0": smart manufacturing of the future. German digitalization experience / Proceedings of the VI International Forum "Information Modeling for Infrastructure Projects and Business Development of Greater Eurasia". Moscow, 2017 (In Russ.).

4. Astafyeva O.E. Specific features in formation of sustainable industrial development mechanism based on efficient use of natural resources. Vestnik universiteta (GUU), 2020, (7), pp. 45-50. (In Russ.).

5. Astafyeva O.E. Formation of the mechanism of sustainable development of the coal industry. Ugol', 2021, (3), pp. 10-13. (In Russ.). DOI: 10.18796/00415790-2021-3-10-13.

6. Timofeyeva T.B. \& Ozdoeva E.A. Analysis of global experience in digital platform development and associated risks. Upravlenie, 2020, Vol. 8, (3), pp. 112-122. (In Russ.).

7. Toffler E. Shock of the Future. Moscow, AST Publ., 2002, 557 p. (In Russ.). 8. Naisbitt J. Megatrends. Moscow, AST Publ., Yermak Publ., 2003, 380 p. (In Russ.). 9. Fukuyama F. The Great Disruption Moscow, AST Publ., Yermak Publ., 2004, 474 p. (in Russ.).

10. Gubanov D.A. Coal production and supply in the Russian Federation / Information and analysis review (March, 2020), Moscow, CDUTEK Publ., 2020, 28 p. (In Russ.).

11. Tarazanov I.G. \& Gubanov D.A. Russia's coal industry performance for January-December, 2019. Ugol', 2020, (3), pp. 54-69. (In Russ.). DOI: 10.18796/00415790-2020-3-54-69.

12. Tarazanov I.G. \& Gubanov D.A. Russia's coal industry performance for January - March, 2020. Ugol', 2020, (6), pp. 23-34. (In Russ.). DOI: 10.18796/00415790-2020-6-23-34.

\section{For citation}

Astafyeva O.E. Formation of a mechanism for the sustainable development of the coal industry based on a new approach to the use of resources in ecosystem interaction. Ugol', 2021, (6), pp. 15-17. (In Russ.). DOI: 10.18796/00415790-2021-6-15-17.

\section{Paper info}

Received March 22, 2021

Reviewed April 27, 2021

Accepted May 17, 2021 